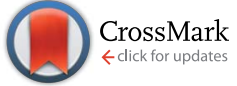

Cite this: RSC Adv., 2017, 7, 7890

Received 9th January 2017

Accepted 20th January 2017

DOI: $10.1039 / c 7 r a 00303 j$

www.rsc.org/advances

\section{A simple synthesis method to prepare a molybdenum oxide hole-transporting layer for efficient polymer solar cells}

\begin{abstract}
Yanping Li, ${ }^{\text {ab }}$ Huangzhong Yu, ${ }^{\text {*a }}$ Xinxin Huang, ${ }^{\text {ab }}$ Zuping Wu ${ }^{\mathrm{ab}}$ and Mingdong Chen ${ }^{\mathrm{a}}$
We report a simple synthetic method to prepare amorphous molybdenum oxide $\left(\mathrm{p}-\mathrm{MoO}_{3}\right)$ using a favorably stable peroxomolybdic acid organosol as the precursor solution prepared by an ultrasonic reaction for the first time. The favorably smooth and dense surface morphology of the $\mathrm{p}-\mathrm{MoO}_{3}$ layers are obtained under $150{ }^{\circ} \mathrm{C}$ thermal treatment with good optical properties and a high work function $\left(W_{\mathrm{F}}\right)$ of $5.26 \mathrm{eV}$. During the annealing treatment two different oxidation states of Mo ions are observed with increasing the annealing temperature to $150{ }^{\circ} \mathrm{C}$ and $200{ }^{\circ} \mathrm{C}$. The best performance of the $\mathrm{P} 3 \mathrm{HT}: \mathrm{PC}{ }_{71} \mathrm{BM}$ devices with $\mathrm{p}-\mathrm{MoO}_{3}$ anode buffer layers has been achieved under $150{ }^{\circ} \mathrm{C}$ treatment with a power conversion efficiency (PCE) of $4.02 \%$, a $V_{O C}$ of $0.59 \mathrm{~V}$, a $J_{S C}$ of $10.70 \mathrm{~mA} \mathrm{~cm}^{-2}$, and a $\mathrm{FF}$ of $63.7 \%$, superior to the corresponding PEDOT:PSS modified devices. Furthermore, the performance of the PTB7:PC ${ }_{71} B M$ devices with the annealed $\mathrm{p}-\mathrm{MoO}_{3}$ buffer layers has also been dramatically improved with the best performance parameters of a PCE of $8.46 \%$, a $V_{\text {OC }}$ of 0.73 , a $J_{\text {SC }}$ of $17.02 \mathrm{~mA} \mathrm{~cm}{ }^{-2}$, a FF of $68.1 \%$ for $150{ }^{\circ} \mathrm{C}$. The improved performance of the devices originates from the following factors; (i) the favorable and

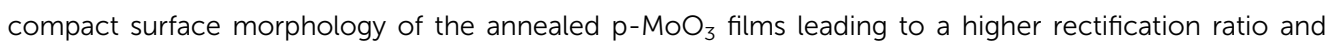
lower leakage current. (ii) The formation of oxygen vacancies and the growing $\mathrm{Mo}^{5+}$ cation leading to the change of $W_{F}$ under the annealing treatment. The highest $W_{F}$ of $5.26 \mathrm{eV}$ for $150{ }^{\circ} \mathrm{C}$ treatment influences the built-in electric field of the devices with the photocurrent being extracted efficiently at a short-circuit.
\end{abstract}

\section{Introduction}

In recent years the development of bulk heterojunction (BHJ) polymer solar cells (PSCs) continues to show progress, ${ }^{1-7}$ and PSCs have also been a hot research topic due to their advantages of low-cost manufacturing, light weight and good flexibility. ${ }^{8-11}$ A BHJ polymer solar cell generally consists of a transparent anode (typically indium tin oxide, ITO), a BHJ active layer (a mixture of donor polymer and fullerene acceptor), and a cathode (e.g. $\mathrm{Al}, \mathrm{Ca} / \mathrm{Al}$ or $\mathrm{LiF} / \mathrm{Al})$. Anode/cathode interfacial layers are usually used as charge selective contacts between the BHJ active layer and the electrodes. The development of appropriate electron (or hole) charge blocking and opposite transporting charge layers is paramount to the fabrication of more efficient solution processed PSC devices. The role of such layers is also to create asymmetrical interfaces to enable reduced recombination of photogenerated electrons and holes at the electrodes and collect charge effectively. ${ }^{12}$

${ }^{a}$ School of Physics and Optoelectronics, South China University of Technology, Guangzhou 510640, China. E-mail: hzhyu@scut.edu.cn; Tel: +86-20-87110768

${ }^{b}$ School of Materials Science \& Engineering, South China University of Technology, Guangzhou 510640, China
Nowadays the aqueous poly(3,4-ethylenedioxythiophene):poly(styrene sulfonate) (PEDOT:PSS) is typically used as the anode buffer layer in PSCs. However, PEDOT: PSS has the hygroscopic and acidic nature with an associated reduction in device stability. ${ }^{13,14}$ Therefore, developing a straightforward method to prepare more moderate, stable and effective anode interlayers is highly desirable for the low-cost, high throughput manufacturing of efficient PSC modules. In this regard, transition metal oxide semiconductors including $\mathrm{NiO},{ }^{15,16} \mathrm{MoO}_{3},{ }^{17,18}$ $\mathrm{V}_{2} \mathrm{O}_{5}$ (ref. 19) and $\mathrm{WO}_{3}$ (ref. 20) are emerging as a promising candidates of substitutes for PEDOT:PSS as the hole-transporting layer (HTL), which possess the demonstrable advantages of the wide range of energy level aligning capabilities, high transmittance in the visible region, and excellent ambient stability. Moreover, the developed solution-processed metal oxides semiconductors are compatible with low-cost all-solution highthroughput manufacturing of PSCs. Among these semiconductors, solution-processed $\mathrm{MoO}_{3}$ thin films have been prepared from different precursors such as ammonium molybdate, ${ }^{21-23} \mathrm{MoO}_{2}(\text { acac })_{2},{ }^{24,25} \mathrm{Mo}(\mathrm{CO})_{3}(\mathrm{EtCN})_{3}$ (ref. 26) and dispersed $\mathrm{MoO}_{3}$ nanoparticles ${ }^{27,28}$ and proved to be a promising candidate as efficient hole extraction layers. However, many weak points can be discerned in the above solution-based synthetic methods for $\mathrm{MoO}_{3}$ films, which may ultimately decrease their hole- 
transporting efficiency when they become part of an organic optoelectronic devices. For instance, the inadequately homogeneous surface of $\mathrm{MoO}_{3}$ films that are usually formed, and the high temperature of thermal treatment along with additional process steps (such as oxygen plasma treatment) are generally needed after spin-coating the precursor solution. In addition, the sol-gel method involving dissolution of $\mathrm{MoO}_{3}$ in hydrogen peroxide, and then dispersion with polyethylene glycol and 2methoxyethanol, resulting in smooth $\mathrm{MoO}_{3}$ films after the timeconsuming reflux and high temperature $\left(275{ }^{\circ} \mathrm{C}\right)$ thermal treatment. $^{29,30}$

In this paper, we report a simply synthetic method to prepare the favorably stable dark blue peroxomolybdic acid organosol by the ultrasonic reaction for the first time. Then the molybdenum oxide (marked as $\mathrm{p}-\mathrm{MoO}_{3}$ ) films with varying reduction degrees are prepared using the peroxomolybdic acid organosol as the precursor solution by spin-coating method. The optical characteristic, surface topography and electrical characteristics of $\mathrm{p}-\mathrm{MoO}_{3}$ films annealed in a broad temperature range are compared and discussed in depth. In order to validate the effect of our prepared $\mathrm{p}-\mathrm{MoO}_{3}$ films annealed under various temperature on the OPV devices, the OPV devices with the structures of ITO/HTL/P3HT (or PTB7): $\mathrm{PC}_{71} \mathrm{BM} / \mathrm{LiF} / \mathrm{Al}$ are fabricated. Finally, the mechanism of the efficiency enhancement upon incorporation of $\mathrm{p}-\mathrm{MoO}_{3}$ films as anode buffer layers under various annealing temperatures is proposed.

\section{Experimental section}

Regioregular electron-donor poly(3-hexylthiophene) (Р3HT), poly[[4,8-bis[(2-ethylhexyl)oxy]benzo[1,2- $\left.b: 4,5-b^{\prime}\right]$ dithiophene2,6-diyl][3-fluoro-2-(2-ethylhexy) carbonyl]thieno[3,4- $b]$ thiophenediyl]] (PTB7) and acceptor [6,6]-pheny C71-butyric acid methyl ester $\left(\mathrm{PC}_{71} \mathrm{BM}\right)$ were purchased from Luminescent Technology, Inc. The PEDOT:PSS (Clevios 4083) were purchased from H.C. Starck. The chlorobenzene, 1,2-dichlorobenzene and $\mathrm{MoO}_{3}$ (99.98\%) were purchased from Sigma-Aldrich. All the chemicals were used as received without further purification. The structures of the fabricated PSC devices are ITO/HTL/P3HT (or PTB7): $\mathrm{PC}_{71} \mathrm{BM} / \mathrm{LiF} / \mathrm{Al}$. The structures of the PSC devices, chemical structures and energy level diagram of materials used in the PSC devices are shown in Fig. 1.

\subsection{Preparation of the molybdenum solution}

The synthesis was based on the preparation of the peroxomolybdic acid solution with the treatment of the ultrasonic reaction, which was very crucial for the preparation of the peroxomolybdic acid solution. First, ethanediol and isopropanol were mixed to obtain $40 \mathrm{~mL}$ complex-solvent by the volume ratio of 1 : 9 (ethanediol to isopropanol), then $400 \mathrm{mg} \mathrm{MoO}_{3}$ powder reacted with $40 \mathrm{~mL}$ complex-solvent, and the $30 \%$ aqueous $\mathrm{H}_{2} \mathrm{O}_{2}$ was added to the reacted system by the volume ratio of 7 : $93\left(\mathrm{H}_{2} \mathrm{O}_{2}\right.$ to complex-solvent). The system was dissolved completely after ultrasonication for $30 \mathrm{~min}$, forming the dark blue peroxomolybdic acid organosol (inserted in Fig. 2). The molybdenum concentration was $10 \mathrm{mg} \mathrm{mL}^{-1}$ in mother liquor
$\mathrm{P} 3 \mathrm{HT}$

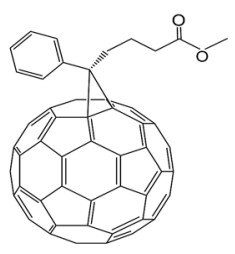

$\mathrm{PC}_{71} \mathrm{BM}$

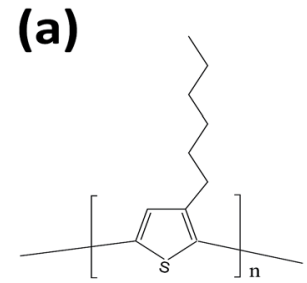

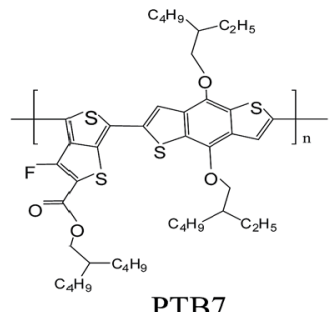

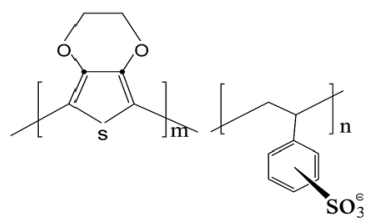

PEDOT:PSS

\section{(b)}
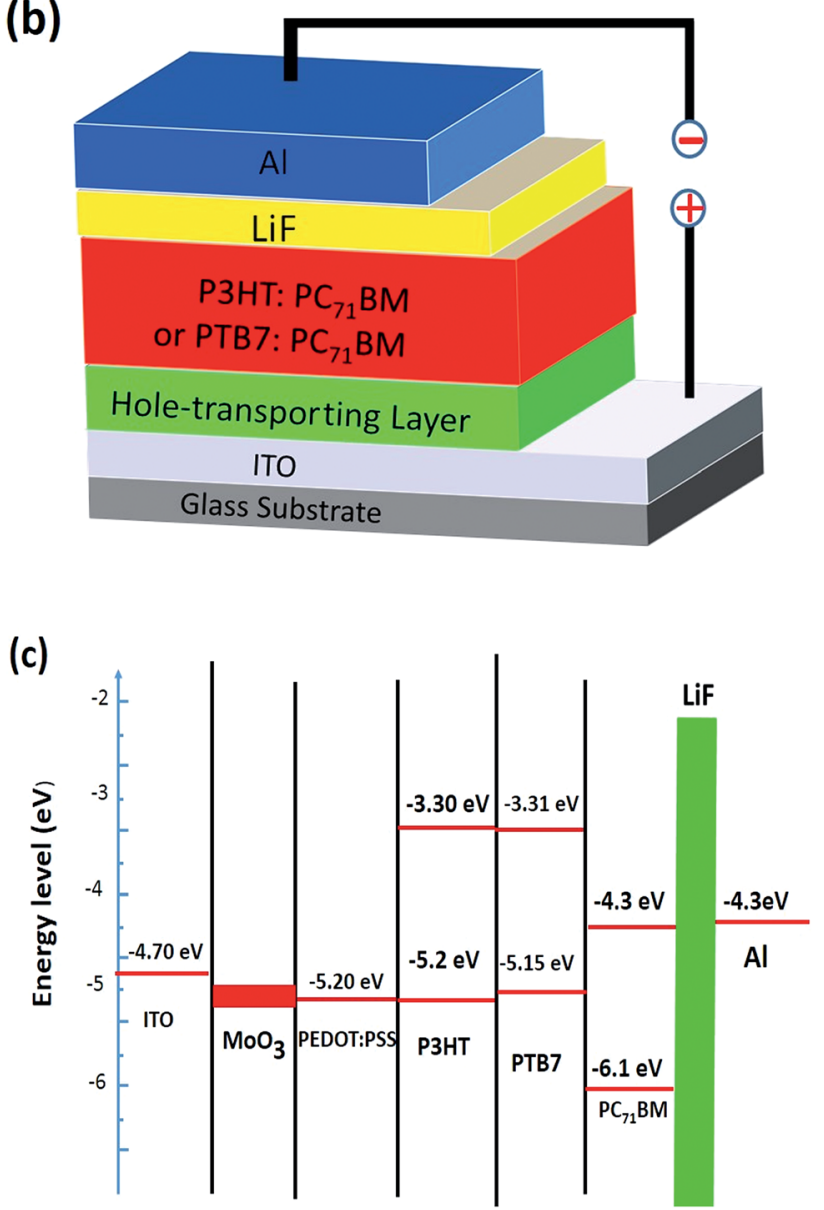

Fig. 1 (a) The molecular structures of P3HT, PTB7, PC ${ }_{71} B M, p-M_{3}$ and PEDOT:PSS. (b) The typical device structure of $\mathrm{P} 3 \mathrm{HT}: \mathrm{PC}_{71} \mathrm{BM}$ or PTB7:PC ${ }_{71} B M$ polymer solar cell. (c) Energy level diagram of the component materials used. ${ }^{2,31}$

and had good dispersion and stability for several months. For each experimental run, the peroxomolybdic acid organosol was diluted with isopropanol to a certain molybdenum concentration. 


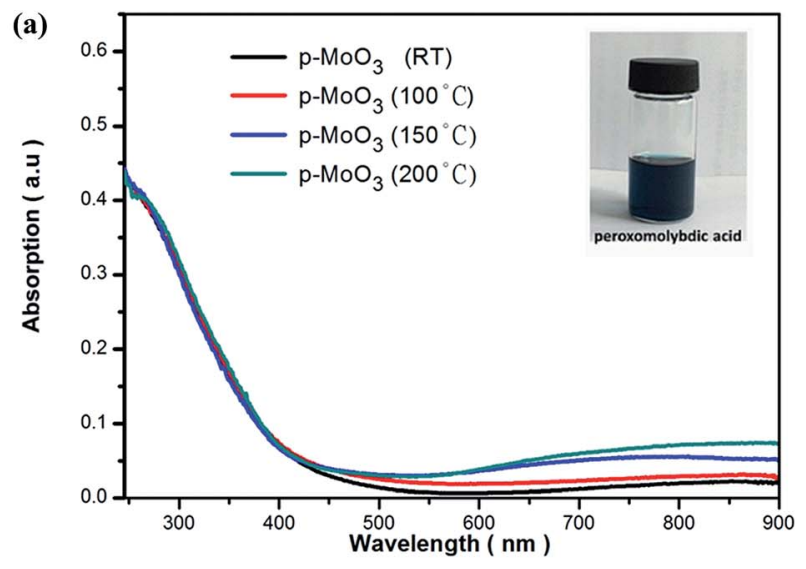

(b)

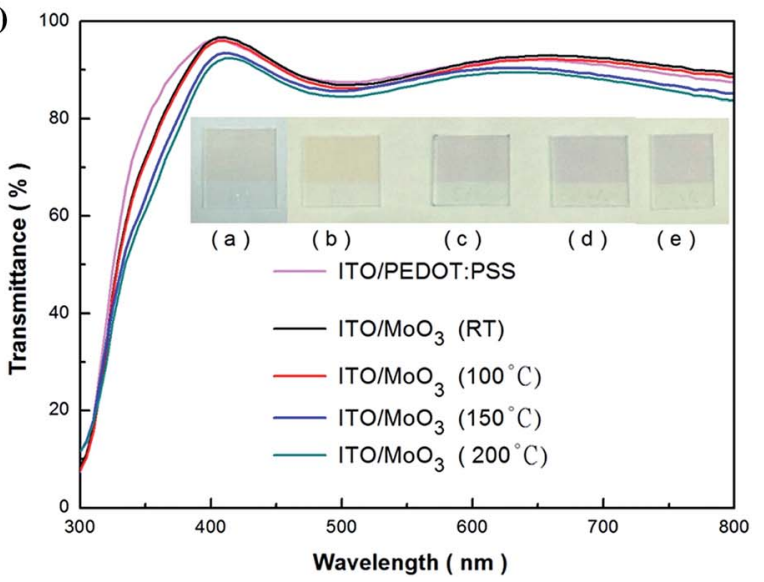

Fig. 2 (a) UV-vis absorption spectra of the $\mathrm{p}-\mathrm{MoO}_{3}$ thin films under various annealing temperature. (b) Transmission spectra of PEDOT:PSS thin film (a) and $\mathrm{p}-\mathrm{MoO}_{3}$ thin films treated with room temperature drying (b), $100{ }^{\circ} \mathrm{C}$ (c), $150{ }^{\circ} \mathrm{C}$ (d), $200^{\circ} \mathrm{C}$ (e).

\subsection{Fabrication of PSC devices}

Prior to device fabrication, the solutions of light-absorbing layer were prepared. Both 1,2-dichlorobenzene solution containing P3HT and $\mathrm{PC}_{71} \mathrm{BM}$ (1:0.8, w/w) and a mixed solvent of chlorobenzene and 1,8-diiodooctane (97:3, v/v) containing PTB7 : $\mathrm{PC}_{71} \mathrm{BM}(1: 1.5, \mathrm{w} / \mathrm{w})$ were stirred in glovebox at $60{ }^{\circ} \mathrm{C}$ overnight. Upon cooling to room temperature, the solutions were filtered through a $0.2 \mu \mathrm{m}$ polytetrafluoroethylene (PTFE) filter before using. The ITO substrates (CSG Holding Co. Ltd., Shenzhen, China) were cleaned by sonication using detergent, deionized water, acetone and isopropanol sequentially for 15 min. After an oven drying for a few hours, the ITO surface was treated with plasma treatment for $10 \mathrm{~min}$. Then the layers of PEDOT:PSS (or peroxomolybdic acid organosol) were spincoated onto the cleaned ITO to obtain the PEDOT:PSS films (or $\mathrm{p}-\mathrm{MoO}_{3}$ films) as an anode buffer layers at $4000 \mathrm{rpm}$ for $40 \mathrm{~s}$ and baked at a certain annealing temperature in glovebox, and the thickness of PEDOT:PSS (or $\mathrm{MoO}_{3}$ ) was about $40 \mathrm{~nm}$ (or 10 $\mathrm{nm}$ ). The molybdenum concentration was diluted with isopropanol to $2 \mathrm{mg} \mathrm{mL}^{-1}$ using mother liquor to regulate the solution viscosity. And the annealing time to construct device HTL in this study was for $20 \mathrm{~min}$. Next, the active layers were spin-coated in the glovebox $\left(\mathrm{O}_{2}<0.1 \mathrm{ppm}, \mathrm{H}_{2} \mathrm{O}<0.1 \mathrm{ppm}\right)$ by employing the active layer solutions. The $\mathrm{LiF}$ and $\mathrm{Al}$ electrode were deposited continuously in a deposition chamber under a basic vacuum pressure lower than $3 \times 10^{-4} \mathrm{~Pa}$. The shadow mask was used during thermal evaporation to define the active area of $0.15 \mathrm{~cm}^{2}$. All devices were unencapsulated and measured in air.

\subsection{Characterization of thin film and PSC devices}

All thickness measurements were analysed using alpha-step surface profiler. Structural assessments of the thin film samples under different annealing temperature via XRD was performed using a Bruker Discovery 08 with a Hi-Star area detector.

The UV-vis absorption and transmittance spectra of the p$\mathrm{MoO}_{3}$ thin films under various annealing temperature and PEDOT:PSS thin film were measured with a HP 8453 UV-vis spectrophotometer.

XPS analysis was carried out on an XPS/ESCA (electron spectroscopy for chemical analysis) instrument (Axis Ultra DLD from Kratos Inc.) utilizing a monochromatized $\mathrm{Al} \mathrm{K} \alpha$ X-ray source. Spectra were referenced to the residual hydrocarbon contamination at $284.6 \pm 0.1 \mathrm{eV}$. The thin films $(c a .40 \mathrm{~nm})$ were deposited on the ITO substrate for XPS analysis.

The work functions of the $\mathrm{p}-\mathrm{MoO}_{3}$ thin film samples under different annealing temperatures were investigated using Kelvin Probe measurements, carried out on a KP Technology SKP5050 in a glove-box filled in a conditioned chamber where the $\mathrm{O}_{2}$ level is $<0.1 \mathrm{ppm}$.

Scanning electron microscope (SEM) and Tapping-mode atomic force microscope (AFM) images using a NanoScope NS3A system (Digital Instruments) were obtained to observe the surface morphology of the annealed films.

The current density-voltage $(J-V)$ characteristics of the devices were performed using a computer controlled Keithley 2400 source-meter under illumination with calibrated AM1.5G $\left(100 \mathrm{~mW} \mathrm{~cm}^{-2}\right)$ at room temperature.

\section{Result and discussion}

\subsection{Optical characteristics of $\mathrm{MoO}_{3}$ thin films}

Firstly the UV-vis measurement was carried on the spin-coated thin films with the same spin-coating conditions and different annealing temperatures. As clearly shown in Fig. 2(a), all the p$\mathrm{MoO}_{3}$ thin films are almost transparent within visible light range, and this will be of benefit for light harvesting. However, a growing small broad absorption ranging from $600 \mathrm{~nm}$ to $800 \mathrm{~nm}$ is observed for the annealed thin films under $150{ }^{\circ} \mathrm{C}$. Increasing the treated temperature to $200{ }^{\circ} \mathrm{C}$, this small broad absorption becomes more evident. This fascinating phenomenon may be attributed to the free electrons being trapped in oxygen vacancies in these $\mathrm{p}-\mathrm{MoO}_{3}$ thin films. ${ }^{32}$

In accordance with the condition of device fabrication, we further investigated the transmission spectra of the thin films including PEDOT:PSS film to evaluate the transparency of these films in devices (Fig. 2(b)). These films are spin-coated on ITO 


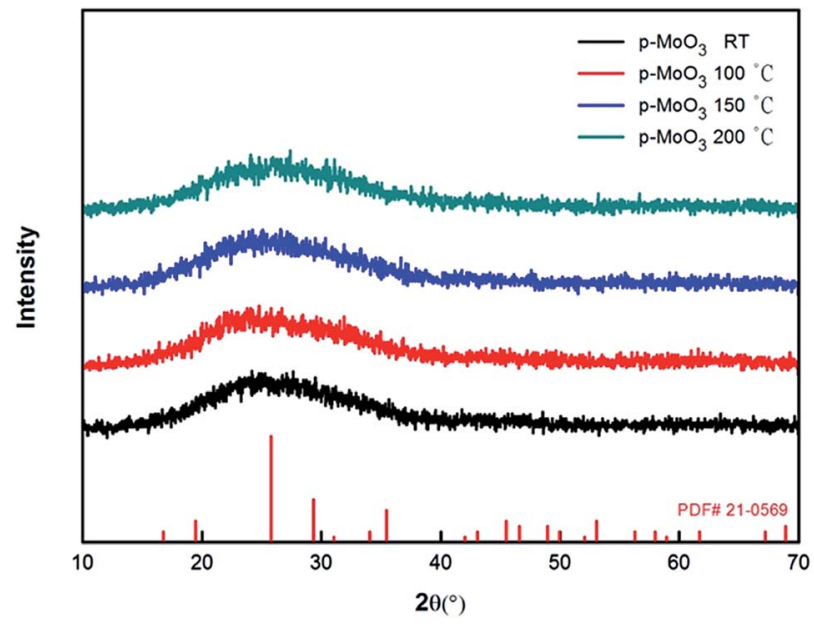

Fig. 3 XRD pattern of the resulting $\mathrm{p}-\mathrm{MOO}_{3}$ thin films annealed under various temperatures.

glasses. It is obvious that transmission values of all the films show good light transmittance except in the wavelength near $500 \mathrm{~nm}$ and $750 \mathrm{~nm}$. This phenomenon is attributed to the transparency of ITO glass and small broad absorption mentioned above. ${ }^{33,34}$ Nevertheless, the transmission values are above $80 \%$ for all films regardless of the annealing temperature, implying that $\mathrm{p}-\mathrm{MoO}_{3}$ thin films are qualified to be good interfacial later without significant absorption losses.

\subsection{Morphology of the $\mathrm{p}-\mathrm{MoO}_{3}$ thin film}

Then XRD measurements were performed on $\mathrm{p}-\mathrm{MoO}_{3}$ thin films deposited on ITO substrates and annealed in glovebox with different annealing temperatures. Fig. 3 shows the XRD patterns of $\mathrm{p}-\mathrm{MoO}_{3}$ thin films that are formed at various heat treated temperatures, the $\mathrm{p}-\mathrm{MoO}_{3}$ layers do not yield significant diffraction peaks as confirmed by XRD as shown in Fig. 3, which shows that these $\mathrm{p}-\mathrm{MoO}_{3}$ thin films have an amorphous structure. But these $\mathrm{p}-\mathrm{MoO}_{3}$ thin films with amorphous structure have been demonstrated to be effective to the device performance. ${ }^{24,25,35}$

To understand the surface morphology of the annealed films, SEM and AFM were performed to observe the morphology characteristics of the p- $\mathrm{MoO}_{3}$ films. Fig. 4 shows SEM images of the annealed $\mathrm{p}-\mathrm{MoO}_{3}$ thin films with different annealing temperatures. It is clear that the surface under the condition of room temperature drying is quite uneven and not uniform with some obvious small $\mathrm{MoO}_{3}$ gains. However, it can also be noted that the surface become much flatter with the increase of heating temperature. We attribute this phenomenon to the evaporation of the solvent and progress of $\mathrm{p}-\mathrm{MoO}_{3}$ thin film formation. When the annealing temperature is increased to $150{ }^{\circ} \mathrm{C}$, surface topography of the $\mathrm{p}-\mathrm{MoO}_{3}$ thin film is the most flat and uniform without any small gains. At this point, the heat treatment makes the film more compact, which prevents the current leakage of the solar cells, and is beneficial to the improvement of the devices. But further raising the annealing temperature to $200{ }^{\circ} \mathrm{C}$, thin film appears critically gathered
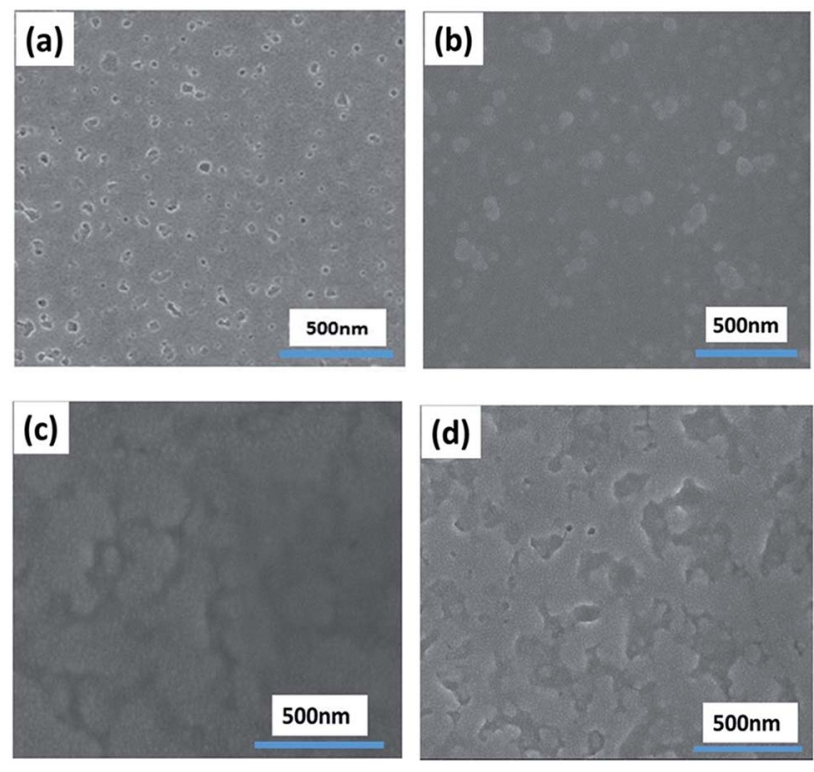

Fig. 4 SEM images of the thin films morphology of $\mathrm{p}-\mathrm{MoO}_{3}$ thin films morphology on ITO treated with room temperature drying (a), $100{ }^{\circ} \mathrm{C}$ (b), $150{ }^{\circ} \mathrm{C}$ (c), $200{ }^{\circ} \mathrm{C}$ (d).

aggregation phenomenon and less uniform. This can be due to enhanced surface diffusion of the species leading to smaller grains joining together to grow into larger grains.

Fig. 5 shows AFM images of the $\mathrm{p}-\mathrm{MoO}_{3}$ thin films with different annealing temperatures. The surface roughness (in Root Mean Square, RMS) of the $\mathrm{p}-\mathrm{MoO}_{3}$ thin film treated with different annealing temperatures is $2.36 \mathrm{~nm}, 2.12 \mathrm{~nm}, 1.46 \mathrm{~nm}$ and $1.51 \mathrm{~nm}$ for room temperature drying, $100{ }^{\circ} \mathrm{C}, 150{ }^{\circ} \mathrm{C}$ and $200{ }^{\circ} \mathrm{C}$, respectively. The $\mathrm{p}-\mathrm{MoO}_{3}$ thin films treated with heat treatment of $150{ }^{\circ} \mathrm{C}$ possess the lowest surface roughness, which is quite well consistent with the result of SEM images. Low surface roughness of the $\mathrm{p}-\mathrm{MoO}_{3}$ thin film suggests that they can smoothen the ITO substrate surface effectively to avoid local shorts and at the same time be dense enough to prevent the current leakage, which is prerequisites to guarantee their implementation as effective buffer layer for organic electronics.

\subsection{Components and electrical characterization of $\mathrm{p}-\mathrm{MoO}_{3}$ thin films}

X-ray photodectron spectroscopy (XPS) shown in Fig. 6 was operated to obtain the evidence for the composition of the p$\mathrm{MoO}_{3}$ thin films treated with various annealing temperature. The binding energy (BE) obtained in the XPS analysis was corrected for specimen charge by referencing the $\mathrm{C} 1 \mathrm{~s}$ peak to $284.6 \mathrm{eV}$. Fig. 6(a) compares the full scan spectra of the annealed $\mathrm{p}-\mathrm{MoO}_{3}$ thin films, the characteristic peaks of the $\mathrm{O}$ 1s, Mo 3s, Mo 3p and Mo 3d levels are shown in the full spectra of the $\mathrm{p}-\mathrm{MoO}_{3}$ thin films. Moreover, no other peaks of the impurity and ITO substitute are found, which suggests that the synthetic precursor can be spread uniformly and completely decomposes to $\mathrm{p}-\mathrm{MoO}_{3}$ by annealing. In Fig. 6(b), the Mo 3d doublet presents a spin-orbit splitting between the Mo $3 \mathrm{~d} 3 / 2$ 

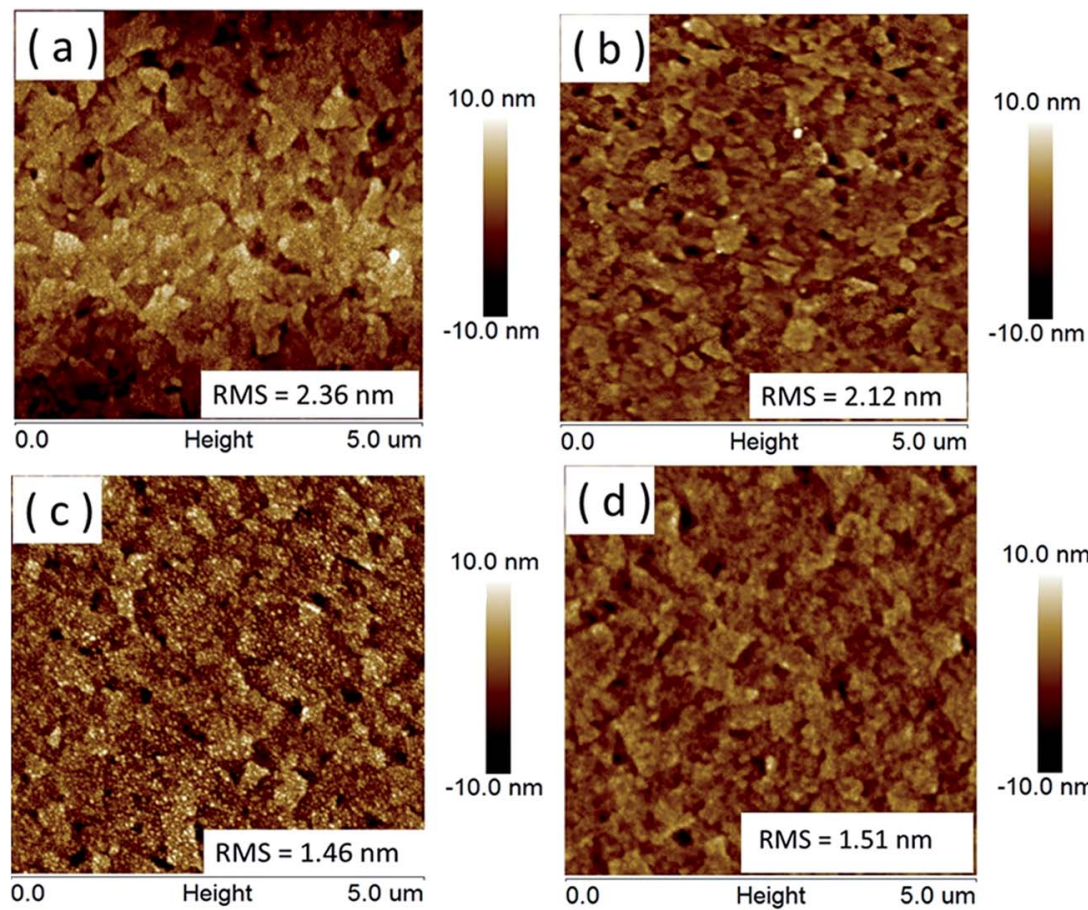

$10.0 \mathrm{~nm}$

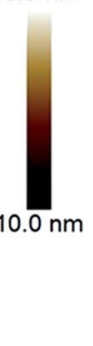

Fig. 5 AFM morphology images of $\mathrm{p}-\mathrm{MoO}_{3}$ thin films on ITO treated with room temperature drying (a), $100{ }^{\circ} \mathrm{C}$ (b), $150{ }^{\circ} \mathrm{C}$ (c), $200{ }^{\circ} \mathrm{C}$ (d).
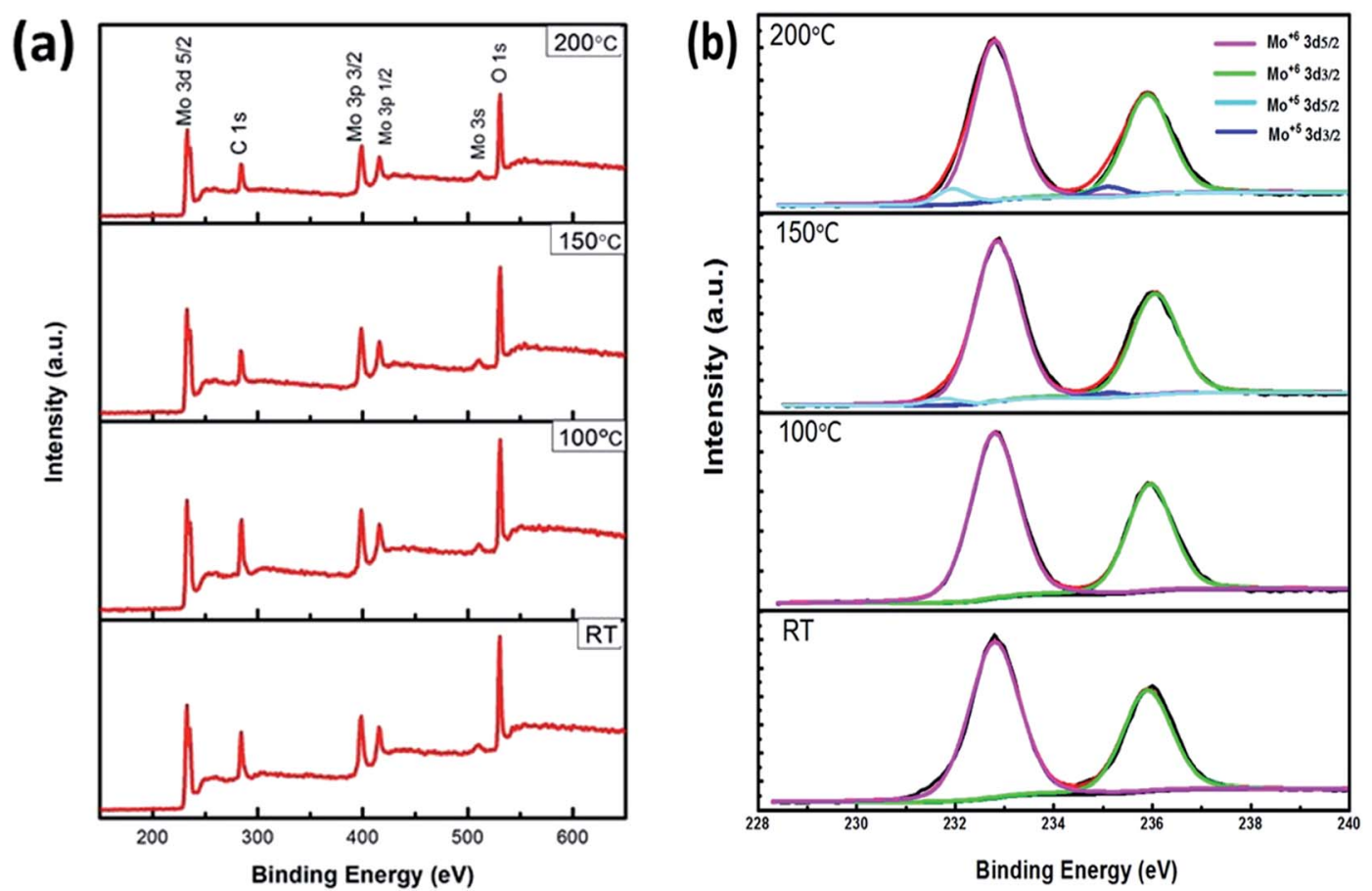

Fig. 6 X-ray photoelectron spectroscopy of $\mathrm{p}-\mathrm{MoO}_{3}$ thin films. (a) Full scanned spectra, (b) Mo 3d core level of thin films treated with various annealing temperature.

and $3 \mathrm{~d} 5 / 2$ bands. The Mo $3 \mathrm{~d} 3 / 2$ and $3 \mathrm{~d} 5 / 2$ peaks of the $\mathrm{p}-\mathrm{MoO}_{3}$ films treated under RT and $100{ }^{\circ} \mathrm{C}$ located at 232.8 and $235.9 \mathrm{eV}$, respectively. The lines of doublet are Gaussian with the d intensity ratio of $2: 3$, separated by $3.1 \mathrm{eV}$. It is apparent that the position of the Mo (3d) lines is expected for $\mathrm{Mo}^{6+}$ ions as in $\mathrm{p}-\mathrm{MoO}_{3} .^{30,36,37}$

However, two different oxidation states of Mo ions are observed with further increasing the annealing temperature to 
$150{ }^{\circ} \mathrm{C}$ and $200{ }^{\circ} \mathrm{C}$, the positions of newly formed $\mathrm{Mo}^{5+}$ peaks in the $150{ }^{\circ} \mathrm{C}$ and $200{ }^{\circ} \mathrm{C}$ annealed films fitted by two $3 \mathrm{~d} 5 / 2$ and $3 \mathrm{~d} 3 / 2$ doublets in the form of a Gaussian function located $231.7 \mathrm{eV}$ and $234.9 \mathrm{eV}$, respectively, which is identified as $\mathrm{Mo}^{5+} \cdot{ }^{38,39}$ While the positions of $\mathrm{Mo}^{6+}$ peaks annealed films has not changed with further improve the annealing temperature. The calculated $\mathrm{Mo}^{5+} / \mathrm{Mo}^{6+}$ ratios for the $150{ }^{\circ} \mathrm{C}$ and $200{ }^{\circ} \mathrm{C}$ annealed films are 0.030 and 0.071 , respectively. By using the $\mathrm{Mo}^{5+} / \mathrm{Mo}^{6+}$ obtained from the Mo $3 \mathrm{~d}$ core level spectra, the estimated Mo:O stoichiometries of $\mathrm{p}-\mathrm{MoO}_{3}$ films annealed in the $150{ }^{\circ} \mathrm{C}$ and $200{ }^{\circ} \mathrm{C}$ are 2.99 and 2.96 , respectively. It can be ascribed that the concentration of the $\mathrm{Mo}^{5+}$ component in the $\mathrm{p}$ $\mathrm{MoO}_{3}$ films is greatly connected with thin film processing conditions, which coincides with the fact that preparation of $\mathrm{p}$ $\mathrm{MoO}_{3}$ in the oxygen deficient environment (in glovebox) and annealing temperatures led to present $\mathrm{Mo}^{5+}$ states, corresponding to the electron transfer from $\mathrm{O} 2 \mathrm{p}$ to Mo $4 \mathrm{~d}$ and generation of oxygen vacancies..$^{39-42}$

To further evaluate the energetics of the solution-processed $\mathrm{p}-\mathrm{MoO}_{3}$ thin films under annealing conditions, Kelvin probe (KP) analysis was performed to obtain the work function $\left(W_{\mathrm{F}}\right)$ of annealed films in glovebox referring to literature. ${ }^{26}$ Kelvin probe analysis of the PEDOT:PSS coated on ITO as a reference gives a $W_{\mathrm{F}}$ of $5.20 \mathrm{eV}$, which is in agreement with the literature. ${ }^{2}$ The $W_{\mathrm{F}}$ of annealed $\mathrm{p}-\mathrm{MoO}_{3}$ thin films shows a gradual shift towards the higher values from $4.90 \mathrm{eV}$ to $5.26 \mathrm{eV}$ with increasing annealing temperatures from RT to $150{ }^{\circ} \mathrm{C}$, reaching the highest $W_{\mathrm{F}}$ value of $5.26 \mathrm{eV}$ with $150{ }^{\circ} \mathrm{C}$. We attribute this phenomenon to the desorption of adsorbates and evaporation of the solvent. ${ }^{43,44}$ With further increasing the annealing temperature to $200{ }^{\circ} \mathrm{C}$, the $W_{\mathrm{F}}$ value of the film decreases slightly to $5.22 \mathrm{eV}$. The main reason may be linked with the distinctly reduced cation oxidation shown in Fig. 6(b) and occupied oxygen vacancy defect states within the band that played the part of donor levels. The $W_{\mathrm{F}}$ values are shown in Table 1.

\subsection{Effect of the $\mathrm{p}-\mathrm{MoO}_{3}$ thin film on the performance of PSCs}

To investigate the effect of the $\mathrm{p}-\mathrm{MoO}_{3}$ buffer layer on the photovoltaic performance of PSCs, firstly we selected the P3HT:PC ${ }_{71}$ BM blended composite as the light-absorbing layer and constructed some solar cells. Device structures of P3HT: $\mathrm{PC}_{71} \mathrm{BM}$ solar cells fabricated with $\mathrm{p}-\mathrm{MoO}_{3}$ thin films treated with various annealing temperatures are presented as follow:

Table $1 W_{F}$ values of anode interface coated with PEDOT:PSS and $\mathrm{MoO}_{3}$ by Kelvin probe evolution

\begin{tabular}{lll}
\hline Anode interface & $T\left({ }^{\circ} \mathrm{C}\right)$ & $W_{\mathrm{F}}(\mathrm{eV})$ \\
\hline $\mathrm{PEDOT}^{\text {PSS }}$ & 150 & 5.20 \\
$\mathrm{p}-\mathrm{MoO}_{3}$ & $\mathrm{RT}$ & 4.90 \\
$\mathrm{p}-\mathrm{MoO}_{3}$ & 100 & 5.10 \\
$\mathrm{P}^{-\mathrm{MoO}_{3}}$ & 150 & 5.26 \\
$\mathrm{p}-\mathrm{MoO}_{3}$ & 200 & 5.22
\end{tabular}

(A) ITO/PEDOT:PSS $\left(150{ }^{\circ} \mathrm{C}\right) / \mathrm{P} 3 \mathrm{HT}: \mathrm{PC}_{71} \mathrm{BM} / \mathrm{LiF} / \mathrm{Al}$.

(B) ITO/p- $\mathrm{MoO}_{3}(\mathrm{RT}) / \mathrm{P} 3 \mathrm{HT}: \mathrm{PC}_{71} \mathrm{BM} / \mathrm{LiF} / \mathrm{Al}$.

(C) ITO/p- $\mathrm{MoO}_{3}\left(100{ }^{\circ} \mathrm{C}\right) / \mathrm{P} 3 \mathrm{HT}: \mathrm{PC}_{71} \mathrm{BM} / \mathrm{LiF} / \mathrm{Al}$.

(D) ITO/p- $\mathrm{MoO}_{3} / \mathrm{P} 3 \mathrm{HT}: \mathrm{PC}_{71} \mathrm{BM} / \mathrm{LiF} / \mathrm{Al}$.

(E) ITO/p- $\mathrm{MoO}_{3}\left(200{ }^{\circ} \mathrm{C}\right) / \mathrm{P} 3 \mathrm{HT}: \mathrm{PC}_{71} \mathrm{BM} / \mathrm{LiF} / \mathrm{Al}$.

Devices $\mathrm{A}$ is the control sample with a PEDOT:PSS buffer layer, devices B, C, D and E are samples with the annealed p$\mathrm{MoO}_{3}$ layer. The device performance parameters are summarized in Table 2.

$J-V$ curves of devices A-E under the illumination of AM1.5G, $100 \mathrm{~mW} \mathrm{~cm} \mathrm{~cm}^{-2}$ are depicted in Fig. 7(a). For device A with PEDOT:PSS buffer layer, it shows a PCE of $3.91 \%$ with a shortcircuit current density $\left(J_{\mathrm{SC}}\right)$ of $10.50 \mathrm{~mA} \mathrm{~cm} \mathrm{~cm}^{-2}$, an open-circuit voltage $\left(V_{\mathrm{OC}}\right)$ of $0.59 \mathrm{~V}$, and a fill factor $(\mathrm{FF})$ of $63.1 \%$. In contrast, the four parameters $\left(V_{\mathrm{OC}}, J_{\mathrm{SC}}, \mathrm{FF}\right.$, and PCE) of devices with the $\mathrm{p}-\mathrm{MoO}_{3}$ buffer layer exhibit different degrees of growth under the annealing temperature increased from RT to $150{ }^{\circ} \mathrm{C}$. The device with the $\mathrm{p}-\mathrm{MoO}_{3}$ anode buffer layer annealed at $150{ }^{\circ} \mathrm{C}$ shows the best PCE of 4.02 , with a $V_{\text {OC }}$ of $0.59 \mathrm{~V}$, a $J_{\text {SC }}$ of $10.70 \mathrm{~mA} \mathrm{~cm} \mathrm{~cm}^{-2}$, and a $\mathrm{FF}$ of $63.7 \%$, which is better than that using the PEDOT:PSS buffer layer (PCE $=3.91 \%$ ). Further increasing the annealing temperature to $200{ }^{\circ} \mathrm{C}$, the device performance is decreased apparently with a PCE of $3.78 \%$, a $V_{\text {OC }}$ of $0.58 \mathrm{~V}, \mathrm{a} J_{\mathrm{SC}}$ of $10.36 \mathrm{~mA} \mathrm{~cm}{ }^{-2}$, and a $\mathrm{FF}$ of $62.9 \%$.

A closer look at the $J-V$ curves are shown in Fig. 7(b), we can find that the both reverse current density and leakage current of the devices are reduced with the increase of heat treatment p$\mathrm{MoO}_{3}$ buffer layer, and the devices for $150{ }^{\circ} \mathrm{C}$ possess the lowest reverse current density and leakage current. This is because the $150{ }^{\circ} \mathrm{C}$ heat treatment makes the film more compact, which has fewer defects, reduces charge recombination, and is beneficial to the improvement of the devices. Moreover, the rectification ratio of the devices calculated based on the $J-V$ curves at $\pm 1.0 \mathrm{~V}$ is also calculated. For devices A, B, C, D and E, the rectification ratio is $2.2 \times 10^{3}, 2.0 \times 10^{2}, 5.1 \times 10^{2}, 3.1 \times 10^{3}$ and $1.1 \times 10^{3}$, respectively. Clearly the rectification ratio values of devices $\mathrm{D}$ and $\mathrm{E}$ with the $\mathrm{p}-\mathrm{MoO}_{3}$ buffer layer annealed under $150{ }^{\circ} \mathrm{C}$ and $200{ }^{\circ} \mathrm{C}$ are simultaneously higher than that of device $\mathrm{B}$ and $\mathrm{C}$ with the $\mathrm{p}-\mathrm{MoO}_{3}$ buffer layer under temperature drying and annealed under $100{ }^{\circ} \mathrm{C}$. Series resistance $R_{\mathrm{s}}$ and shunt resistance $R_{\text {sh }}$ are clear as shown in Table 2. $R_{\text {sh }}$ of P3HT:PC ${ }_{71} \mathrm{BM}$ based devices with $\mathrm{p}-\mathrm{MoO}_{3}$ buffer layer annealed at $150{ }^{\circ} \mathrm{C}$ is $1145.46 \Omega \mathrm{cm}^{2}$, which is much greater than the devices with $\mathrm{p}$ $\mathrm{MoO}_{3}$ buffer layer without annealing (639.03 $\left.\Omega \mathrm{cm}^{2}\right)$, annealed at $100{ }^{\circ} \mathrm{C}\left(743.96 \Omega \mathrm{cm}^{2}\right)$ and at $200{ }^{\circ} \mathrm{C}\left(921.46 \Omega \mathrm{cm}^{2}\right)$. This is presumably due to the increase of compact density of the film surface (see Fig. 4(c) and 5(c)), leading to the decrease of charge recombination and leakage current, which is also in agreement with the Fig. $7(\mathrm{~b})$. Moreover, the $R_{\mathrm{S}}$ of the devices decrease with the increase of heat treatment $\mathrm{p}-\mathrm{MoO}_{3}$ buffer layer, and the value of $8.08 \Omega \mathrm{cm}^{2}$ for the device with $\mathrm{p}-\mathrm{MoO}_{3}$ layer annealed $150{ }^{\circ} \mathrm{C}$ is the lowest among those devices with $\mathrm{p}-\mathrm{MoO}_{3}$ layer other heat treatment temperature. Increase of heat treatment temperature usually causes the reduction of molybdenum oxide, which leads to rise in conductivity of molybdenum oxide. In general, reduced transition metal oxides (TMOs) not only shows an increase in conductivity, but also causes stronger 
Table 2 Performance parameters of $\mathrm{P} 3 \mathrm{HT}: \mathrm{PC}_{71} \mathrm{BM}$ solar cells fabricated with annealed $\mathrm{p}-\mathrm{MoO}_{3}$ thin films

\begin{tabular}{|c|c|c|c|c|c|c|c|}
\hline Device & $T\left({ }^{\circ} \mathrm{C}\right)$ & $J_{\mathrm{SC}}\left(\mathrm{mA} \mathrm{cm} \mathrm{cm}^{-2}\right)$ & $V_{\mathrm{OC}}(\mathrm{V})$ & $\mathrm{FF}(\%)$ & $R_{\mathrm{s}}\left(\Omega \mathrm{cm}^{2}\right)$ & $R_{\mathrm{sh}}\left(\Omega \mathrm{cm}^{2}\right)$ & PCE (\%) \\
\hline A & 150 & 10.50 & 0.59 & 63.1 & 8.15 & 968.57 & 3.91 \\
\hline B & $\mathrm{RT}$ & 8.49 & 0.57 & 56.9 & 10.50 & 639.03 & 2.75 \\
\hline $\mathrm{D}$ & 150 & 10.70 & 0.59 & 63.7 & 8.08 & 1145.46 & 4.02 \\
\hline $\mathrm{E}$ & 200 & 10.36 & 0.58 & 62.9 & 8.20 & 921.46 & 3.78 \\
\hline
\end{tabular}
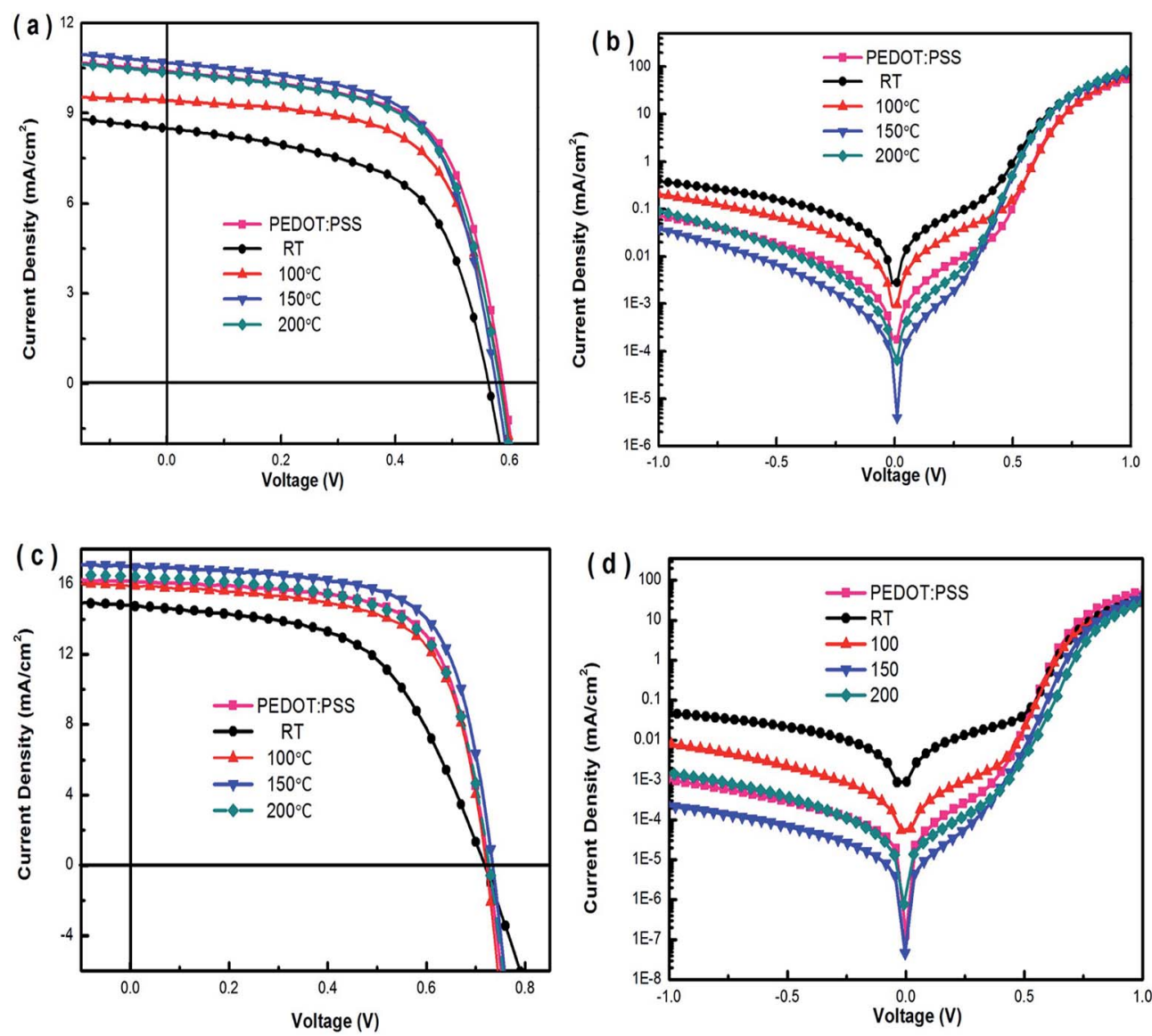

Fig. $7 \mathrm{~J}-V$ characteristic curve of different devices fabricated with annealed $\mathrm{p}-\mathrm{MoO}_{3}$ thin films under illumination and in the dark. (a, b) P3HT:PC ${ }_{71} B M$ solar cells under illumination and in the dark, $(c, d)$ PTB7:PC ${ }_{71} B M$ solar cells under illumination and in the dark.

optical absorption. ${ }^{45}$ We attribute this interesting phenomenon to a result of the forming process of $\mathrm{p}-\mathrm{MoO}_{3}$ and a slightly nonstoichiometric composition with some oxygen deficiency leading to reduced oxides.

The improved PCE of devices with annealed $\mathrm{p}-\mathrm{MoO}_{3}$ hole transporting layers (HTL) may origin from the following factors; (i) the favorable surface morphology of the annealed $\mathrm{p}-\mathrm{MoO}_{3}$ HTL. As shown in SEM images (Fig. 4) and AFM images (Fig. 5), the $\mathrm{p}-\mathrm{MoO}_{3}$ HTL spin-coated on ITO substrates without the annealing is quite not smooth and dense compared to substrates, leading to the poor device performance. By increasing the annealing temperature, the $\mathrm{p}-\mathrm{MoO}_{3}$ surface is growing smoother and compacter with the optimum surface and smallest roughness (RMS) of $1.46 \mathrm{~nm}$ for $150{ }^{\circ} \mathrm{C}$, This decreased roughness accounts for the different dark $J-V$ characteristics (Fig. 7(b)) of the devices with p- $\mathrm{MoO}_{3}$ layer annealed various temperatures, in which the devices exhibit increasingly excellent diode characteristics with higher rectification ratio and lower leakage current under reverse bias with improved annealing temperature. It means that the annealed $\mathrm{p}-\mathrm{MoO}_{3}$ layer is capable of lowering the leakage current caused by the disagreeable roughness of ITO substrate. Further improving the annealing temperature leads to the slight aggregation and rising back of roughness. Therefore, the contact between the $\mathrm{p}$ $\mathrm{MoO}_{3}$ layer and the active layer becomes less favorable to the hole extraction.

(ii) The formation of oxygen vacancies and the growing $\mathrm{Mo}^{5+}$ cation leading to the change of $W_{\mathrm{F}}$ under the annealing. UV-vis 
absorption spectra analysis (Fig. 2(a)) indicates the formation of oxygen vacancies of the annealed $\mathrm{p}-\mathrm{MoO}_{3}$ layer started with the annealing temperature $150{ }^{\circ} \mathrm{C}$ and the amount of oxygen vacancies further increased with improved temperature to $200{ }^{\circ} \mathrm{C}$, which is all consistent with the XPS analysis as presented in Fig. 6. During annealing treatment, small amount of oxygen vacancies generated owing to the process of dehydration and desorption is capable of causing effective n-type doping for $150{ }^{\circ} \mathrm{C}$, which is greatly conducive to the improved performance of the devices D with a PCE of $4.02 \%$, the further increasing amount of oxygen vacancies with improved temperature to $200{ }^{\circ} \mathrm{C}$ leads to a slightly declined PCE of $3.78 \%$. Furthermore, the oxygen ion vacancies of the substoichiometric $\mathrm{p}-\mathrm{MoO}_{3}$ are occupied by two electrons and acted as donor centres with the donor level at $0.27 \mathrm{eV}$ below the conduction band, the charge transfer from oxygen vacancies to Mo ions creates reduce $\mathrm{d}$ oxidation states of $\mathrm{Mo}^{5+}$. It is reported that a general correlation between cation oxidation state and an oxide's $W_{\mathrm{F}}$ is that metal oxides in their more oxidized forms tend to have higher work functions than their reduced forms. ${ }^{43}$ Therefore, the increasing change of the $W_{\mathrm{F}}$ from $4.90 \mathrm{eV}$ to $5.22 \mathrm{eV}$ under the annealing from RT to $200{ }^{\circ} \mathrm{C}$ couples with a fluctuation of the highest $W_{\mathrm{F}} 5.26 \mathrm{eV}$ for $150{ }^{\circ} \mathrm{C}$, which influences the built-in electric field of the devices and the photocurrent being extracted efficiently at short-circuit.

In order to further testify the possibility of general usage of the $\mathrm{p}-\mathrm{MoO}_{3}$ layer as a hole-transporting layer under the mild thermal-annealing in polymer solar cells, we also prepare the devices with the structures of $\mathrm{PTB} 7: \mathrm{PC}_{71} \mathrm{BM}$ solar cells fabricated with PEDOT:PSS and $\mathrm{p}-\mathrm{MoO}_{3}$ thin films treated with various annealing temperatures as following:

(F) ITO/PEDOT:PSS $\left(150{ }^{\circ} \mathrm{C}\right) / \mathrm{PTB} 7: \mathrm{PC}_{71} \mathrm{BM} / \mathrm{LiF} / \mathrm{Al}$.

(G) $\mathrm{ITO} / \mathrm{p}-\mathrm{MoO}_{3}(\mathrm{RT}) / \mathrm{PTB} 7: \mathrm{PC}_{71} \mathrm{BM} / \mathrm{LiF} / \mathrm{Al}$.

(H) ITO/p- $\mathrm{MoO}_{3}\left(100^{\circ} \mathrm{C}\right) / \mathrm{PTB} 7: \mathrm{PC}_{71} \mathrm{BM} / \mathrm{LiF} / \mathrm{Al}$.

(I) ITO/p- $\mathrm{MoO}_{3}\left(150^{\circ} \mathrm{C}\right) / \mathrm{PTB} 7: \mathrm{PC}_{71} \mathrm{BM} / \mathrm{LiF} / \mathrm{Al}$.

(J) $\mathrm{ITO} / \mathrm{p}-\mathrm{MoO}_{3}\left(200^{\circ} \mathrm{C}\right) / \mathrm{PTB} 7: \mathrm{PC}_{71} \mathrm{BM} / \mathrm{LiF} / \mathrm{Al}$.

In Fig. $7(\mathrm{c})$, the $J-V$ characteristics of the $\mathrm{PTB} 7: \mathrm{PC}_{71} \mathrm{BM}$ devices under AM1.5G illumination are presented. It is evident that the annealing to $\mathrm{p}-\mathrm{MoO}_{3}$ layer induces large improvement in $J_{\mathrm{SC}}$ from $14.78 \mathrm{~mA} \mathrm{~cm}^{-2}$ to $16.43 \mathrm{~mA} \mathrm{~cm}^{-2}$ and $\mathrm{FF}$ from $54.9 \%$ to $65.1 \%$ with the annealing temperature from RT to $200{ }^{\circ} \mathrm{C}$. The best $J_{\mathrm{SC}}, \mathrm{FF}$ and PCE of the p- $\mathrm{MoO}_{3}$-based devices is 17.02 $\mathrm{mA} \mathrm{cm}{ }^{-2}, 68.1 \%$ and $8.46 \%$ for $150{ }^{\circ} \mathrm{C}$, respectively, which apparently surpass the PEDOT-based devices with a $J_{\mathrm{SC}}$ of 16.17 $\mathrm{mA} \mathrm{cm}{ }^{-2}, \mathrm{FF}$ of $67.2 \%$ and PCE of $7.93 \%$. The performance parameters are summarized in Table 3.
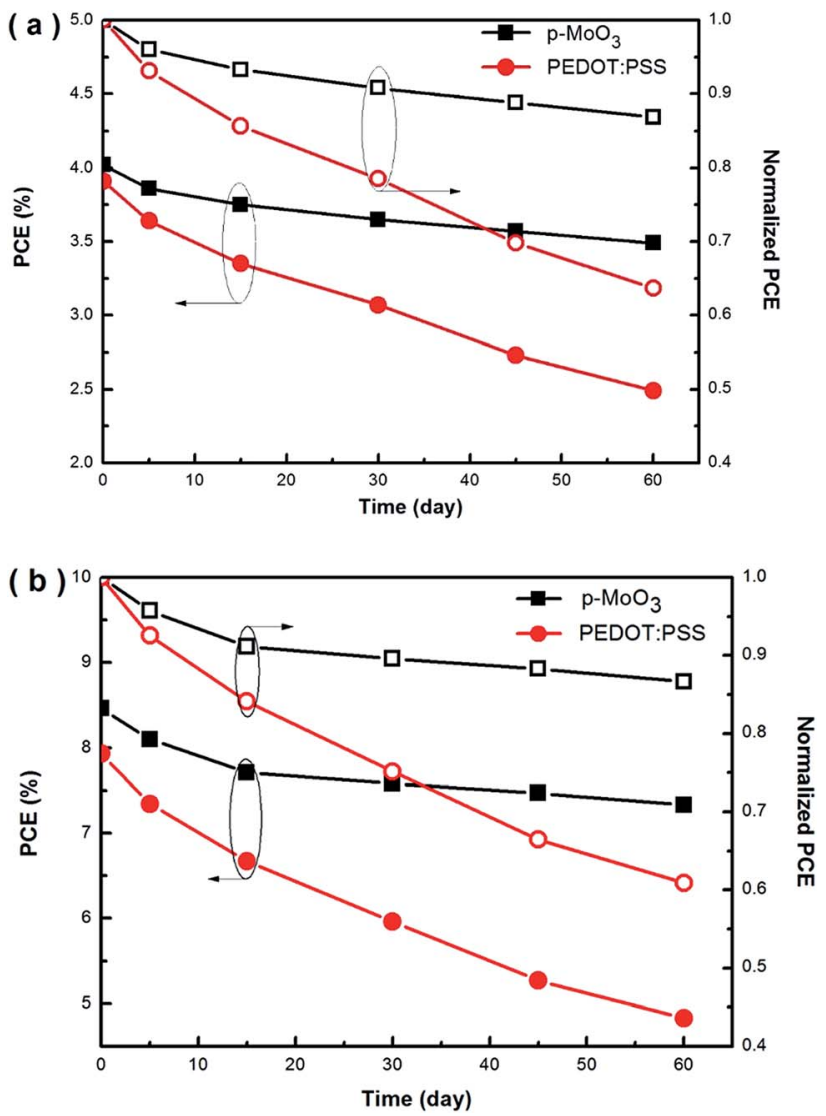

Fig. 8 PCEs and normalized PCEs as functions of aging time of $\mathrm{P} 3 \mathrm{HT}: \mathrm{PC}_{71} \mathrm{BM}(\mathrm{a})$ and PTB7:PC ${ }_{71} \mathrm{BM}(\mathrm{b})$ devices incorporating $\mathrm{p}-\mathrm{MoO}_{3}$ thin films.

As a consequence, the devices with the $\mathrm{p}-\mathrm{MoO}_{3}$ films annealed at $150{ }^{\circ} \mathrm{C}$ exhibit the largest increase in performance with the best PCE of $8.46 \%$, further confirming that our prepared $\mathrm{p}-\mathrm{MoO}_{3}$ thin films annealed at moderate temperature are fit for the PTB7:PC ${ }_{71} \mathrm{BM}$ devices due to the favorable surface morphology and electrical properties as discussed above. Meanwhile, according to the leakage dominated region $(<0.5 \mathrm{~V})$ as shown in Fig. $7(d)$, the dark current of the PTB7:PC ${ }_{71} \mathrm{BM}$ devices with the annealed $\mathrm{p}-\mathrm{MoO}_{3}$ thin films present the trend toward miniaturization with the minimum at $150{ }^{\circ} \mathrm{C}$, which is much less than that of the device $\mathrm{F}$ with PEDOT:PSS. This also indicates that $\mathrm{p}-\mathrm{MoO}_{3}$ thin film is more efficient in holecollection and electron-blocking when served as a HTL in PTB7:PC ${ }_{71} \mathrm{BM}$ BHJ devices.

Table 3 Performance parameters of PTB7:PC 71 BM solar cells fabricated with annealed $\mathrm{p}-\mathrm{MoO}_{3}$ thin films

\begin{tabular}{|c|c|c|c|c|c|c|c|}
\hline Device & $T\left({ }^{\circ} \mathrm{C}\right)$ & $J_{\mathrm{SC}}\left(\mathrm{mA} \mathrm{cm}^{-2}\right)$ & $V_{\mathrm{OC}}(\mathrm{V})$ & $\mathrm{FF}(\%)$ & $R_{\mathrm{S}}\left(\Omega \mathrm{cm}^{2}\right)$ & $R_{\mathrm{sh}}\left(\Omega \mathrm{cm}^{2}\right)$ & PCE (\%) \\
\hline $\mathrm{F}$ & 150 & 16.17 & 0.73 & 67.2 & 5.05 & 1174.06 & 7.93 \\
\hline G & RT & 14.78 & 0.72 & 54.9 & 13.35 & 705.19 & 5.85 \\
\hline I & 150 & 17.02 & 0.73 & 68.1 & 4.49 & 1275.09 & 8.46 \\
\hline $\mathrm{J}$ & 200 & 16.43 & 0.73 & 65.1 & 4.82 & 976.58 & 7.81 \\
\hline
\end{tabular}


Apart from device efficiency, device stability is another important aspect affecting the realization of commercial polymer solar. In this study, we find that the devices with $\mathrm{p}-\mathrm{MoO}_{3}$ thin film exhibit enhanced stability. All of these devices constructed as described in Section 2.2 are not encapsulated and stored in the glovebox filled with nitrogen atmosphere $\left(\mathrm{O}_{2}<\right.$ $\left.0.1 \mathrm{ppm}, \mathrm{H}_{2} \mathrm{O}<0.1 \mathrm{ppm}\right)$. We choose the devices with $\mathrm{p}-\mathrm{MoO}_{3}$ and PEDOT:PSS thin films annealed at optimal annealing temperature $150{ }^{\circ} \mathrm{C}$ as tested objects. Fig. 8 displays the PCEs and normalized PCEs as a function of aging time, of P3HT:PC ${ }_{71} \mathrm{BM}$ and PTB7:PC $\mathrm{PC}_{71} \mathrm{BM}$ devices incorporated $\mathrm{p}-\mathrm{MoO}_{3}$ thin films. For P3HT: $\mathrm{PC}_{71} \mathrm{BM}$ devices as shown in Fig. 8(a), the PCEs decrease dramatically for the devices fabricated with PEDOT:PSS and reach from $3.91 \%$ to $2.40 \%$ after 60 days, only keeping about $60 \%$ of their initial efficiencies. In comparison, the p- $\mathrm{MoO}_{3}$-based P3HT: $\mathrm{PC}_{71} \mathrm{BM}$ devices get PCEs of $3.40 \%$ after storage for 60 days, remaining about $85 \%$ of their initial efficiencies (from $4.02 \%$ to $3.40 \%$ ). On the other hand, Fig. 8 (b) presents the stability of $\mathrm{PTB} 7: \mathrm{PC}_{71} \mathrm{BM}$ devices with different HTL. The PEDOT-based devices degrade rapidly after 60 days with about $40 \%$ decay of PCEs (from $7.93 \%$ to $4.83 \%$ ), whereas the devices incorporating the p- $\mathrm{MoO}_{3}$ HTLs get only $13.3 \%$ decay of PCEs (from $8.46 \%$ to $7.33 \%$ ) after 60 days, revealing the high stability of the $\mathrm{p}-\mathrm{MoO}_{3}$ interfaces. Clearly, it is indicated that the devices incorporating the $\mathrm{p}-\mathrm{MoO}_{3}$ thin films exhibit higher stability.

\section{Conclusions}

The favorably stable dark blue peroxomolybdic acid organosol is simply synthesized by the treatment of the ultrasonic reaction. The prepared $\mathrm{p}-\mathrm{MoO}_{3}$ films were characterized from the spectroscopic measurements, SEM, AFM, XPS analysis, and Kelvin probe analysis. It is found that the favorably smooth and dense surface morphology of the $\mathrm{p}-\mathrm{MoO}_{3}$ layers are obtained under $150{ }^{\circ} \mathrm{C}$ with the good optical and electrical properties. Furthermore, the performance of the $\mathrm{P} 3 \mathrm{HT}: \mathrm{PC}_{71} \mathrm{BM}$ and $\mathrm{PTB} 7: \mathrm{PC}_{71} \mathrm{BM}$ devices with $\mathrm{p}-\mathrm{MoO}_{3}$ thin films is found to depend strongly on the annealing and show best performance for $150{ }^{\circ} \mathrm{C}$. The improved performance of devices origin from the factors; (i) the favorable surface morphology of the annealed $\mathrm{p}-\mathrm{MoO}_{3}$ films leading to higher rectification ratio and lower leakage current. (ii) The formation of oxygen vacancies and the growing $\mathrm{Mo}^{5+}$ cation leading to the change of $W_{\mathrm{F}}$ under the annealing. Furthermore, the devices containing $\mathrm{p}-\mathrm{MoO}_{3}$ thin film exhibited enhanced environmental stability. Overall, the simple and stable peroxomolybdic acid solution that we have developed is a viable candidate for replacing the PEDOT:PSS anode modifying layers in many organic solar cells including other electronic devices that require an ultrasmooth and high $W_{\mathrm{F}}$ solution-processed hole selective contact.

\section{Acknowledgements}

This work was financially supported by the National Natural Science Foundation of China (Grant No. 61474046 and 61176061).

\section{References}

1 G. Yu, J. Hummelen, F. Wudl and A. J. Heeger, Polymer photovoltaic cells: Enhanced efficiencies via a network of internal donor-acceptor heterojunctions, Science, 1995, 270, 1789-1791.

2 Z. He, C. Zhong, S. Su, M. Xu, H. Wu and Y. Cao, Enhanced power-conversion efficiency in polymer solar cells using an inverted device structure, Nat. Photonics, 2012, 6, 591-595.

3 J. You, L. Dou, K. Yoshimura, T. Kato, K. Ohya, T. Moriarty, K. Emery, C. Chen, J. Gao, G. Li and Y. Yang, A polymer tandem solar cell with $10.6 \%$ power conversion efficiency, Nat. Commun., 2013, 4, 1446.

4 Y. Liu, J. Zhao, Z. Li, C. Mu, W. Ma, H. Hu, K. Jiang, H. Lin, H. Ade and H. Yan, Aggregation and morphology control enables multiple cases of high-efficiency polymer solar cells, Nat. Commun., 2014, 5, 5293.

5 Z. He, B. Xiao, F. Liu, H. Wu, Y. Yang, S. Xiao, C. Wang, T. P. Russell and Y. Cao, Single-junction polymer solar cells with high efficiency and photovoltage, Nat. Photonics, 2015, 9, 174-179.

6 H. Zhou, Y. Zhang, C. Mai, S. D. Collins, G. C. Bazan, T. Nguyen and A. J. Heeger, Polymer Homo-Tandem Solar Cells with Best Efficiency of 11.3\%, Adv. Mater., 2015, 27, 1767-1773.

7 A. R. M. Yusoff, D. Kim, H. P. Kim, F. K. Shneider, W. J. Silvab and J. Janga, A high efficiency solution processed polymer inverted triple-junction solar cell exhibiting a power conversion efficiency of $11.83 \%$, Energy Environ. Sci., 2015, 8, 303-316.

8 J. J. Zhao, B. Z. Xia, K. Lu, D. Deng, L. Yuan, J. Q. Zhang, L. Y. Zhu, X. W. Zhu, H. Li and Z. X. Wei, Dialkoxyphenyldithiophene-based small molecules with enhanced absorption for solution processed organic solar cells, RSC Adv., 2016, 6, 60595-60601.

9 M. C. Scharber and N. S. Sariciftci, Efficiency of bulkheterojunction organic solar cells, Prog. Polym. Sci., 2013, 38, 1929-1940.

10 X. Guo, N. Zhou, S. J. Lou, J. Smith, D. B. Tice, J. W. Hennek, R. P. Ortiz, J. T. L. Navarrete, S. Li, J. Strzalka, L. X. Chen, R. P. H. Chang, A. Facchetti and T. J. Marks, Polymer solar cells with enhanced fill factors, Nat. Photonics, 2013, 7, 825-833.

11 A. J. Heeger, 25th anniversary article: bulk heterojunction solar cells: understanding the mechanism of operation, Adv. Mater., 2014, 26, 10-28.

12 R. Steim, F. R. Kogler and C. J. Brabec, Interface materials for organic solar cells, J. Mater. Chem., 2010, 20, 2499-2512.

13 J. J. Lee, S. H. Lee, F. S. Kim and J. H. Kim, Simultaneous enhancement of the efficiency and stability of organic solar cells using PEDOT:PSS grafted with a PEGME buffer layer, Org. Electron., 2015, 26, 191-199.

14 Y. Sun, J. H. Seo, C. J. Takacs, J. Seifter and A. J. Heeger, Inverted polymer solar cells integrated with a lowtemperature-annealed sol-gel-derived $\mathrm{ZnO}$ film as an electron transport layer, Adv. Mater., 2011, 23, 1679-1683. 
15 L. Zhang, L. Favereau, Y. Farre, A. Maufroy, Y. Pellegrin, E. Blart, M. Hissler, D. Jacquemin, F. Odobel and L. Hammarstrom, Molecular-structure control of electron transfer dynamics of push-pull porphyrins as sensitizers for NiO based dye sensitized solar cells, RSC Adv., 2016, 6, 77184-77194.

16 J. Zhang, J. Wang, Y. Fu, B. Zhanga and Z. Xie, Efficient and stable polymer solar cells with annealing-free solutionprocessible NiO nanoparticles as anode buffer layers, $J$. Mater. Chem. C, 2014, 2, 8295-8302.

17 D. Zhao, S. T. Tan, L. Ke and D. L. Kwong, Optimization of an inverted organic solar cell, Sol. Energy Mater. Sol. Cells, 2010, 94, 985-991.

18 Y. Sun, C. J. Takacs, S. R. Cowan, J. H. Seo, X. Gong, A. Roy and A. J. Heeger, Efficient, Air-Stable Bulk Heterojunction Polymer Solar Cells Using $\mathrm{MoO}_{x}$ as the Anode Interfacial Layer, Adv. Mater., 2011, 23, 2226-2230.

19 K. Shen, R. Yang, D. Wang and K. Ho, Stable CdTe solar cell with $\mathrm{V}_{2} \mathrm{O}_{5}$ as a back contact buffer layer, Sol. Energy Mater. Sol. Cells, 2016, 144, 500-508.

20 T. Stubhan, N. Li, N. A. Luechinger, S. C. Halim, G. J. Matt and C. J. Brabec, High fill factor polymer solar cells incorporating a low temperature solution processed $\mathrm{WO}_{3}$ hole extraction layer, Adv. Energy Mater., 2012, 2, 1433-1438.

21 X. B. Chu, M. Guan, Y. Zhang, Y. Y. Li, X. F. Liu and Y. P. Zeng, ITO-free and air stable organic light-emitting diodes using $\mathrm{MoO}_{3}$ :PTCDA modified $\mathrm{Al}$ as semitransparent anode, RSC Adv., 2013, 3, 9509-9513.

22 K. H. Wong, K. Ananthanarayanan, J. Luther and P. Balaya, Origin of hole selectivity and the role of defects in lowtemperature solution-processed molybdenum oxide interfacial layer for organic solar cells, J. Phys. Chem. C, 2012, 116, 16346-16351.

23 S. Murase and Y. Yang, Solution processed $\mathrm{MoO}_{3}$ interfacial layer for organic photovoltaics prepared by a facile synthesis method, Adv. Mater., 2012, 24, 2459-2462.

24 K. Zilberberg, H. Gharbi, A. Behrendt, S. Trost and T. Riedl, Low-temperature, solution-processed $\mathrm{MoO}_{x}$ for efficient and stable organic solar cells, ACS Appl. Mater. Interfaces, 2012, 4, 1164-1168.

25 Z. Tan, D. Qian, W. Zhang, L. Li, Y. Ding, Q. Xu, F. Wang and Y. Li, Efficient and stable polymer solar cells with solutionprocessed molybdenum oxide interfacial layer, J. Mater. Chem. A, 2013, 1, 657-664.

26 S. R. Hammond, J. Meyer, N. E. Widjonarko, P. F. Ndione, A. K. Sigdel, A. Garcia, A. Miedaner, M. T. Lloyd, A. Kahn, D. S. Ginley, J. J. Berry and D. C. Olson, Low-temperature, solution-processed molybdenum oxide hole-collection layer for organic photovoltaics, J. Mater. Chem., 2012, 22, 32493254.

27 J. Meyer, R. Khalandovsky and P. Görrn, $\mathrm{MoO}_{3}$ Films SpinCoated from a Nanoparticle Suspension for Efficient HoleInjection in Organic Electronics, Adv. Mater., 2011, 23, 7073.

$28 \mathrm{M}$. Xu, L. Cui, X. Zhu and L. S. Liao, Aqueous solutionprocessed $\mathrm{MoO}_{3}$ as an effective interfacial layer in polymer/ fullerene based organic solar cells, Org. Electron., 2013, 14, 657-664.

29 S. Lin, C. Wang, K. Kao, Y. Chen and C. Liu, Electrochromic properties of $\mathrm{MoO}_{3}$ thin films derived by a sol-gel process, $J$. Sol-Gel Sci. Technol., 2010, 53, 51-58.

30 C. Girotto, E. Voroshazi, D. Cheyns, P. Heremans and B. P. Rand, Solution-processed $\mathrm{MoO}_{3}$ thin films as a holeinjection layer for organic solar cells, ACS Appl. Mater. Interfaces, 2011, 3, 3244-3247.

31 F. Cheng, G. Fang, X. Fan and Y. Li, Enhancing the performance of P3HT:ICBA based polymer solar cells using LiF as electron collecting buffer layer and UV-ozone treated $\mathrm{MoO}_{3}$ as hole collecting buffer layer, Sol. Energy Mater. Sol. Cells, 2013, 110, 63-68.

32 T. Yang, M. Wang, Y. Cao, F. Huang, L. Huang, J. Peng, X. Gong, S. Z. D. Cheng and Y. Cao, Polymer Solar Cells with a Low-Temperature-Annealed Sol-Gel-Derived $\mathrm{MoO}_{x}$ Film as a Hole Extraction Layer, Adv. Energy Mater., 2012, 2, 523-527.

33 R. A. Afre, Y. Hayashi and T. Soga, Enhanced photovoltaic device performance upon modification of indium tin oxide coated glass by liquid nitrogen treatment, J. Phys. D: Appl. Phys., 2009, 42, 042002.

34 L. Cattin, F. Dahou, Y. Lare, M. Morsli, R. Tricot, S. Houari, A. Mokrani, K. Jondo, A. Khelil, K. Napo and J. C. Bernède, $\mathrm{MoO}_{3}$ surface passivation of the transparent anode in organic solar cells using ultrathin films, J. Appl. Phys., 2009, 105, 034507.

$35 \mathrm{X} . \mathrm{Yu}$, T. J. Marks and A. Facchetti, Metal oxides for optoelectronic applications, Nat. Mater., 2016, 15, 383-396.

36 F. Xie, W. C. H. Choy, C. Wang, X. Li, S. Zhang and J. Hou, Low Temperature Solution Processed Hydrogen Molybdenum and Vanadium Bronzes for an Efficient Hole Transport Layer in Organic Electronics, Adv. Mater., 2013, 25, 2051-2055.

37 S. Kato, R. Ishikawa, Y. Kubo, H. Shirai and K. Ueno, Efficient Organic Photovoltaic Cells Using HoleTransporting $\mathrm{MoO}_{3}$ Buffer Layers Converted from SolutionProcessed $\mathrm{MoS}_{2}$ Films, Jpn. J. Appl. Phys., 2011, 50, 071604.

38 M. A. Moraes, B. C. Trasferetti, F. P. Rouxinol, R. Landers, S. F. Durrant, J. Scarmínio and A. Urbano, Molybdenum oxide thin films obtained by the hot-filament metal oxide deposition technique, Chem. Mater., 2004, 16, 513-520.

39 M. Anwar, C. A. Hogarth and R. Bulpett, Effect of substrate temperature and film thickness on the surface structure of some thin amorphous films of $\mathrm{MoO}_{3}$ studied by X-ray photoelectron spectroscopy (ESCA), J. Mater. Sci., 1989, 24, 3087-3090.

40 J. J. Jasieniak, J. Seifter, J. Jo, T. Mates and A. J. Heeger, A Solution-Processed $\mathrm{MoO}_{x}$ Anode Interlayer for Use within Organic Photovoltaic Devices, Adv. Funct. Mater., 2012, 22, 2594-2605.

41 Y. Lee, J. Yi, G. F. Gao, H. Koerner, K. Park, J. Wang, K. Luo, R. A. Vaia and J. W. P. Hsu, Low-Temperature SolutionProcessed Molybdenum Oxide Nanoparticle Hole Transport Layers for Organic Photovoltaic Devices, Adv. Energy Mater., 2012, 2, 1193-1197. 
42 K. Kanaia, K. Koizumib, S. Ouchic, Y. Tsukamotoc, K. Sakanouec, Y. Ouchib and K. Sekib, Electronic structure of anode interface with molybdenum oxide buffer layer, Org. Electron., 2010, 11, 188-194.

43 M. T. Greiner, L. Chai, M. G. Helander, W. Tang and Z. Lu, Transition Metal Oxide Work Functions: The Influence of Cation Oxidation State and Oxygen Vacancies, Adv. Funct. Mater., 2012, 22, 4557-4568.
44 Irfan, H. Ding, Y. Gao, C. Small, D. Y. Kim, J. Subbiah and F. So, Energy level evolution of air and oxygen exposed molybdenum trioxide films, Appl. Phys. Lett., 2010, 96, 243307.

45 J. Meyer, S. Hamwi, M. Kröger, W. Kowalsky, T. Riedl and A. Kahn, Transition metal oxides for organic electronics: energetics, device physics and applications, Adv. Mater., 2012, 24, 5408-5427. 